\title{
LITERARY COMPETENCE FOR THE TEACHING OF \\ LITERATURE IN SECOND LANGUAGE EDUCATIONAL CONTEXT
}

\author{
Astri Hapsari \\ Islamic University of Indonesia
}

\begin{abstract}
This essay analyzes the use of literary works in second language educational context. It highlights the importance of literary competence and the implications at stake for the teaching of literature such as: the importance of setting the purpose in teaching literature, the need of considering literature teaching as product versus literature teaching as process and the necessitate of relating literature, language and culture. A brief analysis of the author's experience in using the literary texts in teaching English as a foreign language is also presented. From the discussions of the related literature, further research is recommended to settle the arguments of poetic versus hermeneutic approach in teaching literature as object of study. Moreover, appropriate balance for language, literature and culture for teaching literature as a topic or resources is suggested.
\end{abstract}

Key words: teaching literature, literary competence, second language educational

Context

\section{INTRODUCTION}

The revival of using literary works, such as prose, poetry and drama, in language classrooms has emerged since in the middle of 1980s and 1990s. In English as a second language (ESL) context, literature has been used as a resource "for providing an authentic experience of the target language" (Kramsch \& Kramsch, cited in Nance, 2010, p.2). Literature can also be beneficial for the students in EFL context who rarely use English in their daily conversation because it provides the language use in a context. For example, by reading the dialogues in drama script, the students know how certain expressions are used in a conversation. 
On the other hand, the development of Communicative Language Teaching (CLT) in second language education, which focuses on implementing practical language use, has made the teaching of literature appears to be irrelevant since it is believed that it cannot be easily applied in daily communication. Functional English with specific purpose in tourism, hospitality, business, and so on is in greater demand than a literature discussion class and believed to be free from "any implication of cultural imperialism" (Collie \& Slater, 1987, p.2).

However, keeping away literature in language teaching means diminishing the opportunity to "educate the whole person" (Lazar, 1993, p.19). It is literary works that give the opportunity to involve someone in experiencing certain emotion, questioning certain values, and encouraging them to express an idea about the culture implied in those works. Literary works enable the students to learn about different point of views, enrich the students' perspective and indirectly teach them how to appreciate the differences in the real society.

Reading literary work is different from reading other types of discourse such as newspaper article, an academic journal or textbooks, in which the readers are exposed to certain information without any symbolism or rhythmical choice of words. Literature needs to be interpreted. Culler (2002, p.132) argues that reading literary text requires someone to have an "implicit understanding of the operations of literary discourse which tells one what to look for". He refers this ability as "literary competence" which makes someone converts the meaning beyond what it is written in the text. As a result, the readers have to understand the semiotic signs and the culture which is implicitly written in order to grasp the meaning of a literary work. What is literary competence and how important is the concept for the study of literature in second language educational contexts? This essay will discuss about the definition of literary competence, the importance of the concept for the teaching of literature in second language educational context, and the implications at stake for the teaching of literature in second language educational context.

\section{DEFINITION OF LITERARY COMPETENCE}

The definition of literary competence has been widely discussed by some scholars. Brumfit and Carter (1986, p.18) define literary competence as "an interesting combination of linguistic, socio-cultural, historical, and semiotic awareness". This statement is in line with Culler's idea that if someone reading a 
literature without certain knowledge of "conventions by which fictions are read" (Culler, 2002, p.132), he/she would have no idea how to comprehend the connection between the ideas presented in a literary work even though he/ she might understand the sentences. Moreover, Culler (1997, p. 61) differentiates between what is called poetics and hermeneutics in the study of literature. Poetics starts with the meaning of literary work while hermeneutics starts with form. $\mathrm{He}$ further explains that "the modern tradition of criticism" has submerged in hermeneutics or combined poetics and hermeneutics.

On the other hand, he points out that linguistic model of literary study should have taken poetics as "the first track" (Culler, 1997, p.61). It is poetics, he argues, which describes literary competence which focuses on the conventions that make possible literary structure and meaning: what are the codes or system of convention that enable readers to identify literary genres, recognize plots, create characters out of the scattered details provided in text, identify themes in literary works, and pursue the kind of symbolic interpretation that allows us to gauge the significance of poems and stories. (p.61).From this statement, it is clear that Culler's definition of literary competence focuses on the reader's comprehension about the intrinsic elements of a literary work. Misson (1996) refers Culler's literary competence to "structuralist framework" which the readers develop.

It raises the question, how about culture and history related to the work as proposed by Brumfit's definition of literary competence? Will it be more hermeneutics rather than poetics if culture is highlighted? Should it be only intrinsic elements of the literary work discussed? These questions lead to the issue of critical literacy and aesthetic (Misson and Morgan, 2006). However, in the second language education context, literary competence can be achieved if the study of literary work falls in between poetics and hermeneutics because second language learners may have difficulty to understand the symbolism which they are not familiar with. Symbolism in a literary work is closely related to the culture in which the author is exposed. Each culture might have certain idioms, symbolism, cultural values, social structures, roles, relationships, tradition, belief, genres that can not be found in other cultures (Lazar, 1993). But, it should be noted that the starting point to improve the literary competence should be the comprehension of the intrinsic elements of the literary work. The explanation of history and culture related to the literary work's purpose is to help the process of comprehending it. Thomson (as cited in Misson,1994, p.24) mentions the six levels the readers 
develop in response to the literary work: "attending willingly, elementary perception an comprehension, empathising, analogizing and searching for selfidentity, distanced evaluation of the participants, and reviewing the whole work as the author's creation". All these activities involve the process of making sense of the relationships between the intrinsic elements in a literary work.

\section{THE IMPORTANCE OF THE CONCEPT OF LITERARY COMPETENCE FOR THE TEACHING OF LITERATURE IN THE CONTEXT OF TEACHING ENGLISH TO SPEAKERS OF OTHER LANGUAGES (TESOL)}

Literary competence is not something that is automatically learned. Rosenblatt (as cited in Hall, 2002) argues that in the literary reading events, the reader is in the stage of creating relationship by bringing his/her personal experience, memory and mood in giving the meaning of literary work. This stage, he argues, does not suffice since the reader might have intentional fallacy in reading the literary work and fail to convey the meaning intended by the author. Moreover, Culler (2002) argues that reading a literary text needs an approach with certain preconception, thus; by relying merely on the reader's language competence and experience will not be sufficient .As a consequence, in teaching literature, students must be introduced "some skills which make up literary competence" (Lazar, 1993, p.13). The recognition of the intrinsic elements which construct a literary work can be the starting point to sharpen these skills, for example: in teaching short story, the teacher might start the lesson by introducing an intrinsic element which constructs the short story: the character. The teacher can ask the students to recognize 'How many characters are there in the story?', 'Which one is the main character?', 'Is he/she good or bad?'. Then, the teacher can move to another element: plot by asking question 'What happens to the main character?' and so forth. By doing this, the students will gradually aware of how the story is built, therefore, increasing their awareness to construct the meaning.

In English as a second language (ESL) educational context, Lazar (1993) points out that the degree of how important it is that the students acquire literary competence depends on the purpose in which literature is being used. In an ESL classroom practice, literature is used in various ways. It can be an extract of a novel or poetry used as reading material. It can be a text to be criticized and discussed in a literary study class. Parkinson and Thomas $(2000$, p.1) states the practice of 
teaching literature in the ESL context can range as continuum to what Maley (1989) calls "the use and the study of literature". Moreover, Lazar (1993) argues that literary competence is an essential skill to develop if the study of literature becomes the aim; in contrast, in the case of using literature as a supporting material for language learning, literary competence is learned through the exposure of the text.

These varieties in text's preferences also appear in English as a Foreign Language (EFL) educational context. Reflected on the author's own teaching practice in EFL context at Prayoga Language College in Padang, West Sumatera, Indonesia, a literary work can be used in reading comprehension class or in a literary criticism class.

\section{THE IMPLICATIONS AT STAKE FOR THE TEACHING OF LITERATURE IN SECOND LANGUAGE EDUCATIONAL CONTEXT}

Based on the previous discussion, there are three major implications of literary competence for the study of literature in second language educational context:

1. The importance of setting the purpose in teaching literature (Lazar, 1993 ; Parkinson\& Thomas, 2000; Paran, 2006)

2. The need of considering literature teaching as product versus literature teaching as process (Misson, 1994; Carter \&McRae, 1996; Culler, 1997)

3. The necessitate of relating literature, language and culture ( Valdes, 1986; Lazar, 1993)

\section{The Importance of Setting the Purpose in Teaching Literature}

Setting the purpose of teaching literature is the first thing to consider in an EFL context. "Literature as object of study (type A) and literature as topic/resource (type B)" (Parkinson \& Thomas, 2000) require the learners to different level of literary competence. Paran (2006, p.8) argues that in ESL context "neither of the two extremes exists on its own, and each always includes something of the other". In reflection of the use and the teaching of literary text in Prayoga Language College in Padang, type A is conducted in courses such as Introduction to Literary Study, Short Story, Introduction to English Prose, Poetry, Introduction to English Drama, Literary Criticism, Literature Research Methods and Seminars in Literature. In the end of these courses, the students are expected to be able to 
comprehend a literary work poetically and hermeneutically. Abrams' classification of literature theory (from his book, The Mirror and the Lamp: Romantic Theory and the Critical Tradition) and Wellek and Warren's intrinsic/extrinsic approach (from their book, Theory of Literature), and some literary criticism text books become the frame work to discuss a literary work. In this practice, students are given the choice whether to discuss the literary work from poetics or hermeneutics' side. On the other hand, type B is conducted in courses such as Speaking, Listening, Reading, and Writing. The material used is only an extract of literary work.

The level of literary competence achieved in type A of type B courses will be different. While assessment in Type A requires the students to perform higher order thinking such as analysing and evaluating the literary work, type B's assessment only requires the students to recall and understand the literary text. A critical essay which evaluates or criticizes the literary work is the final assignment for type A courses while information gap activities are typical in type B's assignments. The level of communicative competence of the students taking type B are beginner and lower intermediate while type A is taken by students of upper intermediate and preadvanced level.

\section{The Need of Considering Literature Teaching as Product versus Literature Teaching as Process}

Considering literature teaching as process is essential in order to improve the students' literary competence. In process-based teaching, close reading of the literary work is a must because it needs familiarization of the text's structure in order to grasp the meaning. This issue is what Culler (1997) argues that poetics should be given more priority than hermeneutics so that the readers of literary work are able to appreciate it aesthetically. "Like the text itself, the meanings are, as it were, pre-given," Carter and McRae (1996, p. xxi) argues. Misson (1994, p.1) also highlights the tendency that theories of literature might shift the focus of concerning what an individual text means to "concern with textuality, that is, the concern with "the ways in which readers negotiate with them to produce meaning" and may cause, he emphasis, "the rejection of the individuality of valued texts". Carter \& McRae (1996, p. xxi-xxii) refer it to product based teaching, in which the students may develop "the knowledge about literature" rather than "the knowledge of literature".

In second language learning context, however; often, a critical analysis in a hermeneutic approach helps to improve the students' literary competence. Some 
information about the era when the literature is published and the author's background help the students to make a sense when they find out that the language used in literature is different from what they find in newspapers or magazines. In short, literature teaching as process in ESL context should include both hermeneutic and poetic's side in order to develop students' literary competence.

\section{The Necessitate of Relating Literature, Language and Culture}

Literature can never be divorced from language and culture since it is the product of an author living in a certain era and exposed by certain culture- which might influence the language used. It is more important to consider this case in the era of English as an international language. The number of people speaking English in outer circle and extended circle are even in greater number than the number of people using English from inner circle (Kachru, 1992). It means the literary text used in an English class is not limited from literature written by inner circle authors.

The extent of the culture imposed in the classroom will depend on the purpose for which the literature is being used (Lazar, 1993, p.13). In terms of the study of literature (type A), it's important for the teacher to highlight these features as post-reading discussion because pre-reading discussion will distract them from the focus of reading of the literary text. The culture perspective about these specific features will develop their literary competence. In terms of using literature as a resource for language teaching (type B), the culture perspective will enrich students' pragmatic and discourse competence. Valdes (1986) argues that introducing certain values appeared in the literary work will help the students' comprehension about the text, but the teacher must be aware that this process will not make the students label any stereotypes towards one culture just by reading a piece of literary work.

\section{CONCLUSION}

In conclusion, literary competence is an important concept for the teaching of literature in second language educational context since it sets up a clear definition of what the reader must possess in reading a literary work. Further research is needed to settle the arguments of poetic versus hermeneutic approach and find out the appropriate balance for language, literature and culture for teaching literature in ESL context. 


\section{REFERENCES}

Brumfit, C., \& Carter, R. (1986). Literature and Language Teaching. Oxford; New York: Oxford University Press..

Carter, R.,\& McRae, J. (1994). Language, Literature, and the Learner: creative classroom practice. New York: Addison Wesley Longman.

Collie, J., \& Slater, S. (1987). Literature in the Language Classroom : A Resource Book of Ideas and Activities. Cambridge [Cambridgeshire] ; New York: Cambridge University Press.

Culler, J. (2000). Literary Theory : A Very Short Introduction. Oxford: Oxford University Press.

Culler, J. (2002). Chapter 6: LITERARY COMPETENCE. Structuralist Poetics, 131-152. Retrieved from EBSCOhost.

Hall, G. (2005). Literature in Language Education / Geoff. Hall. New York : Palgrave Macmillan

Kachru, B. B. (1992). The Other Tongue : English Across Cultures / edited by Braj B. Kachru. Urbana: University of Illinois Press

Lazar, G. (1993). Literature and Language Teaching : A Guide for Teachers and Trainers. Cambridge [England] ; New York, NY, USA: Cambridge University Press.

Misson, R., \& Victorian Association for the Teaching of English. (1994). A Brief Introduction to Literary Theory. [Carlton, Vic.]: Victorian Association for the Teaching of English.

Misson, R., \& Morgan, W. (2006). Critical Literacy and the Aesthetic : Transforming the English Classroom. Urbana, Ill.: National Council of Teachers of English.

Nance, K. A. (2010). Teaching Literature in the Languages : Expanding the Literary Circle through Student Engagement (1st ed.). Upper Saddle River, NJ: Prentice Hall.

Paran, A., \& Teachers of English to Speakers of Other Languages. (2006). Literature in Language Teaching and Learning. Alexandria, Va.: Teachers of English to Speakers of Other Languages.

Parkinson, B., \& Thomas, H. R. (2000). Teaching Literature in a Second Language. Edinburgh: Edinburgh University Press. 